\title{
Inter-territorial Creativity of Tyaga Art Management: Acts of Art in Empowering Public Health
}

\author{
Nur Iksan ${ }^{1}$, Mayang Anggrian ${ }^{2}$ \\ \{iksan@ub.ac.id', mayang14@ub.ac.id²\} \\ Universitas Brawijaya, Indonesia ${ }^{1,2}$
}

\begin{abstract}
The correlation between art and culture becomes Tyaga's foundation of creativity oriented to empower the society in the health aspect. Tyaga puts a fundamental domain of art, which is creativity, as the central of combining various cultural and natural elements, rationality and spontaneity in empowering the society. This portion places Tyaga in the relational pattern in creative acts which involves the society directly and inter-territorial approach among various discipline, knowledge, profession, economy, and technology to solve problems in the society. This research is done with a transdisciplinary approach with collegiate participatory action as the research method. The creative pattern done by Tyaga involves midwifes and health cadres in the village through making programs in the form of Upaya Kesehatan yang Bersumber Daya Masyarakat (UKBM/Society Resources Health Efforts), which are innovation program ISUK (Investasi Sampah Untuk Kesehatan/Trash Investation For Health). This Program is exclusive for Bugel villagers, Lamongan district, East Java, Indonesia in POSBINDU PTM (Pos Binaan Terpadu Penyakit Tidak Menular/Integrated Health Post for Non-Communicable Diseases). Here, the researchers position themselves as problem analyzer, giving out opinions, working together with the society to complete each other and the villagers have the position of process controller.
\end{abstract}

Keywords: Creativity, Empowerment, Health, Inter-territorial, Tyaga

\section{Introduction}

Art in the cultural perspective cannot be separated from the contextual relation with time and space when the artwork is being created. This perspective shows that an artwork cannot be separated from the reality on a certain culture, whether it is related to mindset, lifestyle, belief, and even the social norm system in the society. The birth of an artwork could be documentation, representation, and a result of the reflection of the reality faced by the artist. This relation of art and culture emphasizes that an artwork has a special residue from the culture where the artwork was born.

The correlation between art and culture becomes the foundation of Tyaga Art Management's creativity in reflecting the social state. Manifesting in creative acts with society and answer the problems. Practically, Tyaga becomes a part of public empowering process in the health aspect. Putting a fundamental domain of art which is creativity as the central of combining cultural and natural elements, rationality and emotional domain in empowering the society. This portion places Tyaga in the relational pattern in creative acts which involves the society directly and inter-territorial approach among various discipline, knowledge, profession, economy, and technology to solve problems in the society. Here, creative actions of Tyaga act 
as small steps of support for health workers in the middle of decreased trust from the society as the impact of Covid-19 pandemic.

Inter-territorial can be seen from the relation of interdisciplinary and profession: Tyaga Art Management, which tends to move in art management, working together with health workers, also involving village governments, and health cadres with various profession. Interterritorial relation from Tyaga started when midwifes in the village asking Tyaga to help them creating programs for the health problems in the village. With this background, Tyaga initiated collaborative with village midwifes to make an innovative health program in the society for environmental, physical, or psychological health. Innovation program ISUK (Investasi Sampah Untuk Kesehatan/Trash Investation for Health) is a public empowerment program in the development of Usaha Kesehatan Bersumberdaya Masyarakat (UKBM/Society Resources Health Efforts). UKBM is a process to increase knowledge, consciousness, and ability of the individuals, families, and the society to actively involved in health efforts that is done by facilitating problem solving processes through educative and participative approach while also paying attention to the potential necessity and the local social-culture [1].

Innovation of program ISUK is done in Bugel village, Sekaran sub-district, Lamongan district, East Java, Indonesia; in POSBINDU (Pos Binaan Terpadu/Integrated Health Post) for PTM (Penyakit Tidak Menular/Non-Communicable Diseases) checkups. It is intended to realize active participation and independence of the villagers to live healthily. Especially in anticipating non communicable diseases including: hypertension, stroke, diabetes, obesity, thyroid problems, bronchial asthma, chronic kidney disease, and other diseases that do not spread directly from one individual to the other individuals. Practically, ISUK put inorganic trash as a health insurance for the villagers. This means that the villagers exchange their trash to receive medical checkups or treatment for non-communicable disease, and the villagers can save up trash as a form of health infestation for the future.

This research uses transdisciplinary approach where creativity is placed in an epicentrum to solve the problems in the society. Using interdisciplinary approach with collegiate participatory action as the research method, where the researchers positioning themselves as problem analyzer, giving out opinions, working together with the society to complete each other and the villagers have the position of process controller.

\section{Research Method}

Collegiate participatory research method is done because the researchers are Tyaga's members. The researchers collaborate with midwives in Bugel village under the auspices of UPT Puskesmas Sekaran, Sekaran sub-district, Lamongan district, East Java, Indonesia, and involve health cadres to support the success of an empowerment program. This move, in Tyaga's opinion, is an effective and efficient concrete move to solve problems together by making community-based movements in the society.

The data collection technique in this research is done through participation, whether it is participants act in making decisions, interviews, observation, and collecting documents as the proof. After that, the research data is analyzed descriptively with interpretivism approach, then the data is organized and classified based on relevance to find the conclusion.

Data collecting is done through interview by Tyaga member Ayu Nur Aisyah, A. Md. Keb, S. Sn, Bugel midwife Ani Murti Ningsih, A. Md. Keb, village government officials, and health cadres in Bugel village. The data is validated by checking the interview results and comparing 
it with the documentation data in the field, activity reports, and relevant data in the activity done by Tyaga in empowering Bugel villagers.

Transdisciplinary method is chosen because in the research it is not limited to theoretical, but it is factual and practical. Besides, in solving the problems in the society, it is impossible to use one discipline only. But, in the process it can be understood and solved through a transdisciplinary which is implemented in the society. On the International Symposium about transdisciplinary by UNESCO [2], several experts defined that "trans disciplinarity is an integrated knowledge concept and a practice, to handle important issues based on certain procedures integrative". Simply, transdisciplinary is a process characterized by integrated efforts from various discipline (multi-disciplines) to understand an issue or problem [2]. Integration of various disciplines includes:

a. Society empowerment projected by strategies on building an empowered society, having power or ability. A power, whether in the physical, economical, institutional, collaboration, intellectual aspect, and of course it is not separable from a mutual commitment including equality, participation, independence, and sustainability [3].

b. Social psychology, to know each individual in the social scope or society, so the relevant approach is to understand the complexity of the problem faced by human going to a point of observation, which is social psychology. Because social psychology studies human social phenomena in the correlation with social situations [4].

c. Art act; taken from its essence which is creativity by Tyaga to reconcile from various disciplines to solve the problems faced.

d. Health sciences as the health workers to serve public health services.

Practically this research is applied directly on public in the form of public empowerment that is done by Tyaga Art Management. The implementation is done by using a collegiate participatory research method. As the form of the research is based on practice or implementation to public empowerment. A form of collegiate participatory, which is, in quoted Briggs' opinion researchers and the locals work together as colleagues with different skillsets to be included in the learning process together where the locals control the process [5].

\section{Analysis}

Health in the cultural context cannot be separated from the entirety of social interaction, a differential culture that is always negotiated. It means that health problems in the society cannot be seen in the perspective that is similar, inherited, or stagnant for generations. This is proportionate to the ever-changing cultural dynamics. This assumption emphasizes that health problems must be seen in the cultural context or is inseparable from daily lifestyle. The situation of society's social life has a great effect on health. Therefore, a person's health cannot be seen only in physiological aspect, but it must be seen in wider view, such as psychological, economical, state of society, and even political. For example, the higher tendency of hypertension and stroke in African-Americans is interpreted as the result of harsher, high pressure lifestyle, lower income, and racial prejudice [6][7]. So, a person's health can be affected by -other than psyche, by social role and socio-economic factors.

A person's health state is a result of complex interactions of biological factors such as the genetic predisposition and certain disease; psychological factors such as stress; social factors such as the number of social supports received from family and friends [8]. This interaction of multiple factors places artistic actions as a form of collective consciousness by Tyaga Art Management. Borrowing from the teaching of Ki Ageng Suryomentaram: life is an act; 
therefore, people are free from the assumption that life is an object [9]. It means that in their life, humans move (act) as a part of life process, that is the intention of moving for survival such as eating, dressing up, living, or fulfilling survival needs. The more complex orientation, armed with common sense and consciousness, humans in their act as a process to give life experience a meaning.

\subsection{Tyaga Art Management's Art Orientation in Empowering Society}

Tyaga Art Management is an art organization based on art management and culture which was legally built on 2017. Built by Ayu Nur Aisyah, Iksan Breykele, Mayang Anggrian, Mayek Prayitno, and other art practitioners based in Jakarta, Bandung, Yogyakarta, Semarang, Surabaya, Ponorogo, and Malang. Tyaga art organization is based on various fields, from fine art, health, education, and even politics. From this diversity, Tyaga is able to work on interdisciplinary field. Activities done by Tyaga to date, besides art exhibitions, also society empowerment activities, whether it is workshops, residencies, seminars, discussions, facilitating the needs for program socialization from certain organizations, and even program initiations. For sure, the programs held by Tyaga are still in the context of creativity. This made the foundation for Tyaga, besides making activities to distribute art to the public, also organize several trainings as a form of artwork production management. Also, society empowerment activities with collective involvement in solving problems from existing potentials in the society.

Tyaga Art Management as an organization that is used in art management activities, is possible to reach to another art discipline (deterministic). This is done based on its vision: to build a theory-action dialectic consciousness in inclusivity to understand the reality in art and culture. This vision also becomes the art acts of Tyaga to empower the society through health and environmental aspect as a form of inclusivity. This activity is a concrete form of Tyaga's responsibility to the society, a knowledge is not only to be understood and developed, but it is also to be practiced in daily life [10]. Based on this thinking, Tyaga, which typically works in fine art, projects the sciences of art (creativity) to the society concretely to solve the problems in the society.

The motive done by Tyaga is a form of understanding of a theory; that is disciplines are not eternal, but they are ever-changing, develops continuously. If this is true, then every discipline must come out from their hiding, the immutability, to be highlighted by analysis of changes [11]. The context put Tyaga which does not want to be stuck only in art discipline, but having reconciliation consciousness from various disciplines, profession, and personal experiences. Concretely, art is placed on the essential portion which is creativity.

"Creativity is an ability to create compositions, products, or any ideas that is basically is new, and is not known previously by the creator. It is an imaginative activity or synthesis of thoughts whose results are not only conclusions. It may include the making of new patterns and the combination of information's gained from previous experiences and the transplantation of old relations to new situations and may cover all of the creation of new correlation. It must have an agreed intention, not a mere fantasy, although it is a perfect and complete result. It could be able to shape artworks, literature, science products, or maybe procedural or methodological" [12]. 
The explanation emphasizes that the scope of creativity does not only revolve around artifacts, whether it is two-dimensional or three-dimensional, even performance art or film; but creativity can be placed on the procedural aspect or a methodological strategy to be implementable in answering the needs of society. This perception aims at creativity projection done by Tyaga on the reconciliation of various disciplines: art, social psychology, health, and social empowerment sciences. The pattern of reconciliation from various disciplines cannot be separated from creative, iterative, and interactive process that involves Tyaga, village government, village midwives, health cadres and society. This process becomes the base of a public empowerment movement with the motive to learn to solve the problems together with knowledge diffusion to create society's independence in innovating. The reconciliation can identify creative process with inter-territorial process, which is innovation, can also appear from the comparison and the correlation among various discipline such as: science, technology, politics, economy, art, etc. [13].

Art acts of Tyaga in health empowerment in Bugel village as a form of social support, practically inviting the society to be aware of their physical and environmental health. More importantly in the psychological aspect to be aware to live healthily. A collective work that is done consciously by Tyaga as a form of social work. Based on Act 11 Number 11 of 2009 about Social Welfare: the executants of public welfare are individuals, communities, social welfare institutions, and the society that is involved in the execution of social welfare. Here, the portion of Tyaga as an art institution is organizing activities that are oriented in social welfare by making use of resources and available potentials to help social functioning. It means that together with the society to address factual problems and becomes a mediator of social interaction among the society corresponding to the role and the ability to solve the problems.

Work patterns done by Tyaga in the emancipatory perspective, this kind of proactive supports the strategy where social works are intended to raise hopes, confidence, and creative potentials in every individual to face and challenge the dynamics of oppressing powers, sources of structural injustice [14]. This practice is based on one of Tyaga's mission that is building critical, creative, argumentative consciousness in the pluralistic society.

\subsection{Bugel Village Demography: Digging Potential Looking for Solutions}

Bugel village in the perspective of village development is in the self-developing level where a self-developing village has the characteristics of: is not too tied by the customs, starting to use tools and technology, is not isolated and have adequate economy, education, and facilities. Bugel village is one of the villages located on Sekaran sub-district, Lamongan district, East Java province, Indonesia. It is bordering with Bulutengger village on the north and west side, and bordering with Pucuk sub-district on the east and south side geographically. Bugel village has a population count of 982, which breaks down to 464 males and 518 females, 172 people of productive age with 100 job seekers. The highest education level: Primary school 65 people, junior high school 60 people, senior high school 42 people, 3-year diploma 2 people, bachelor degree 1 person and postgraduate 1 person, Islamic boarding school 5 person. The rest are 126 students, and 673 people with no certificate. In the village there are 54 socially poor families, 20 families with poor housing, and 5 families in economic and social risk.

There is one unit of health facility in Bugel village, which is POLINDES. This makes POLINDES as the front in health development with the intention to raise awareness, willingness, and ability of the society to live optimally as a form of human resource development infestation. The health development efforts as a preventive and promotive move, local health workers work together with Tyaga and with health cadres in Bugel village to make the 
innovative program ISUK. Then, in the implementation, prevention, treatment and health recovery is done for the first time in July 2020 where there were 215 cases of PTM, as shown below:

Table 1. Poskendes Report on PTM: Bugel in July 2020

\begin{tabular}{llcccc}
\hline No & \multicolumn{1}{c}{ Disease } & ICD-X & $\begin{array}{c}\text { Old Cases } \\
\text { Total }\end{array}$ & $\begin{array}{c}\text { New Cases } \\
\text { Total }\end{array}$ & $\begin{array}{c}\text { All Cases } \\
\text { Total }\end{array}$ \\
\hline 1. & Hypertension & I10 & 20 & 54 & 74 \\
2. & PPOK & J44 & 1 & 2 & 3 \\
3. & Type II Diabetes Mellitus & E11 & 8 & 20 & 28 \\
4. & Obesity & E66 & 12 & 44 & 56 \\
5. & Bronchial Asthma & J45 & 0 & 2 & 2 \\
6. & Chronic Kidney Disease & N00-N19 & 3 & 0 & 3 \\
7. & Rheumatoid Arthritis & M05.9 & 22 & 60 & 82 \\
\hline
\end{tabular}

The implementation of ISUK in preventing non communicable disease is done continuously once a month with the results of increased enthusiasm of the villagers seen from the number of checkup visits in POSBINDU PTM along with the rising of new non communicable disease cases found in the field and the amount of trash stored to the cadres. The amount of inorganic trash stored increased with each month, which are: $12.50 \mathrm{Kg}$ in July, 33.50 $\mathrm{Kg}$ in August $33.50 \mathrm{Kg}, 59 \mathrm{Kg}$ in September, $72 \mathrm{Kg}$ in October.

Chart 1. Total of checkup visits and PTM on July-October 2020

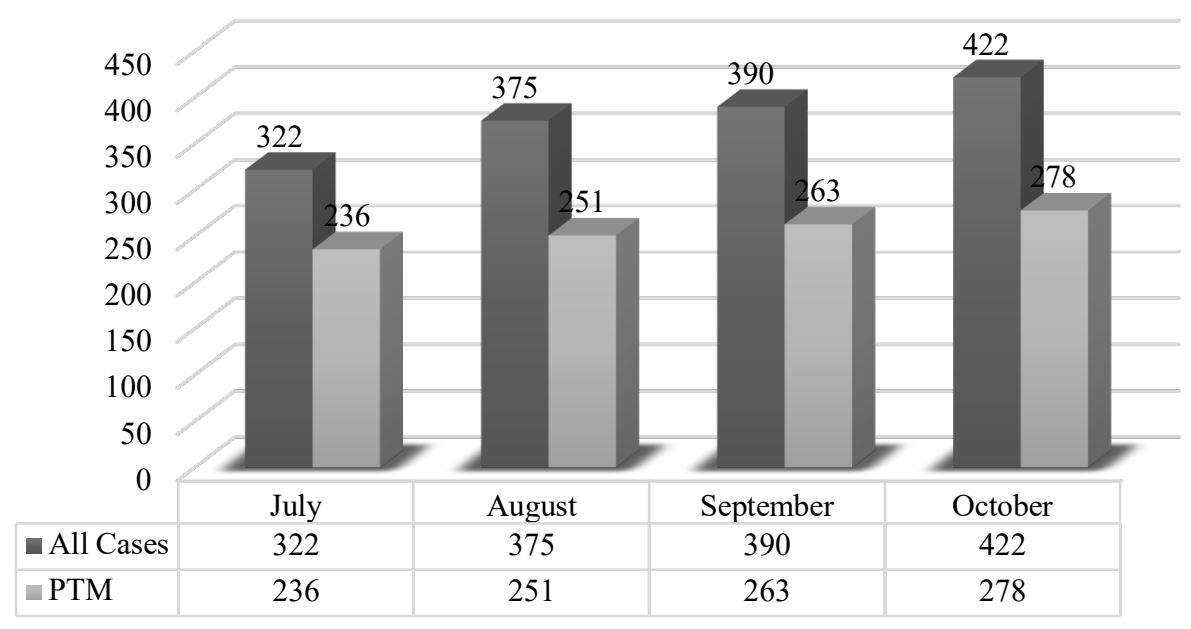

ISUK (Investasi Sampah Untuk Kesehatan/Trash Investation For Health) is a community based social movement with health empowerment principle which is based on environment and economical problem solving for public health insurance, physically, psychologically, and environmentally. Environment is our living space, and resources that we have will greatly affect our vulnerability against diseases and our life expectancy [15].

The Law of the Republic of Indonesia number 36 of 2009 about Health states that health development must be intended to increase society's awareness, willingness, and ability to live healthily as high as possible as an investment for a socially and economically productive human 
resource development. Every person has the right for good health and every person has the same right on having access to health resources. Based on this law, ISUK is intended for building healthy lifestyle awareness and becoming a health insurance for the villagers of Bugel.

Community-based social movements in public health empowerment in Bugel village are emphasized on harnessing available potentials to solve problems. Solving problems as an effort of independence in increasing knowledge, identifying problems, planning and looking for solutions by making use of potentials and facilities around them. A form of society-based problem solving, with the characteristics of.... Focused on skill exchange, helping society members to develop their skills, using skills and wisdom to serve others [16].

In principle, making healthy lifestyle a habit by understanding health in noncommunicable diseases prevention by making use of inorganic trash as a way to get healthcare services. Besides, trash that is typically useless becomes a currency for healthcare services can be saved or invested as health insurance by villagers of Bugel. This pattern is implemented considering inorganic trash which is a global problem can be minimalized from the habit of littering, burning trash, or hoarding trash and helps reduce the amount of trash in landfills (TPA/Tempat Pembuangan Akhir). This strategy places the society to be "melek" (aware) of environmental health, and how the expansion of hygiene control strategies, and the possibility of the awareness to live a healthy life.

\subsection{Villager's Participation in Creating Empowered Village}

The process of public empowerment in ISUK (Investasi Sampah Untuk Kesehatan/Trash Investation for Health) cannot be separated from the participation of Bugel villagers to solve the problem in the society. It can be shown by the villagers' active participation in becoming a subject or a part in solving the problems faced. The turning point of this participation is deciding, acting, and then the society reflects on their action consciously [17]. Society's participation in the social scope leads to the social process with the intention to the creation of competence, creativity, and independence in making decisions (freedom).

The participation is seen in the form of society's involvement by making programs together which is initiated by Tyaga which focused on problem identification, making programs planned and the executor and is executed by the society themselves. This places the society as the subjects of development; actually, this model is the most ideal because it illustrates the capacity of the society in developing their own future [18]. The form of villagers' participation is placed on the model of learning together practically and a part of collective steps which are institutionalized and leads to the sense of belonging in a programmed movement.

This sense of belonging is an important factor in determining the success of a program, marked by collective commitment from all involved society elements. As a form of dedication or binding obligation as a village development movement, it is surely cannot be separated from personal awareness as a social creature. According to Irmawati \& Ridhoi M. Purba, building a relationship with people can fulfill some of human basic needs, individuals on all culture are motivated to build a relationship with people. Individuals have a strong need to be a part of a community [19]. 


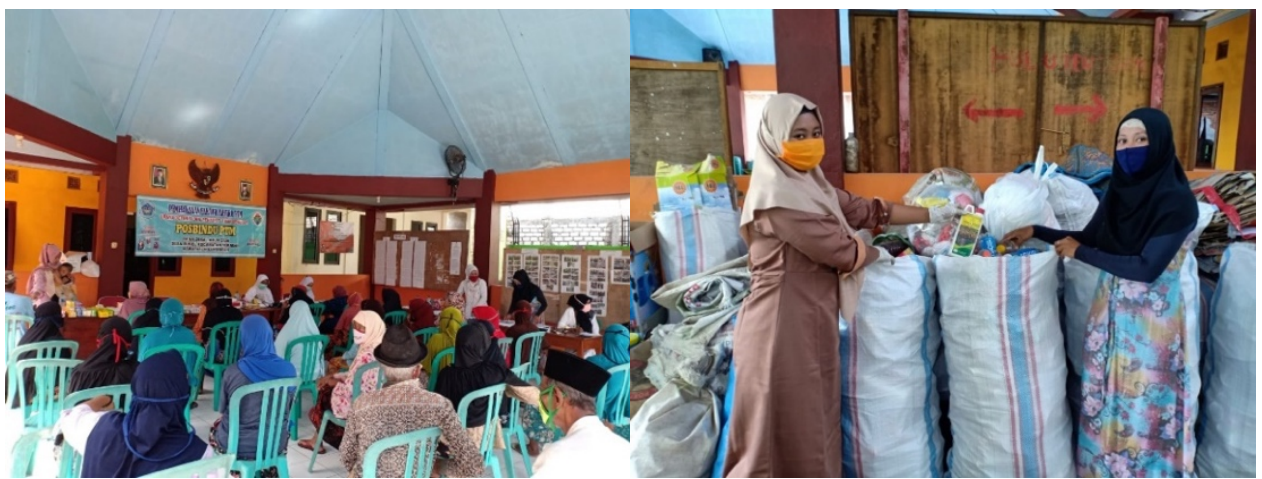

Picture 1. ISUK activities in Bugel village in the village hall on October 2020 (Source: Tyaga Art Management, 2020).

Planning for a development program that is dug from the bottom where it is believed to be the problem and looking for solutions as a form of concrete needs of society is called bottomup development mechanism. This is possible due to the society's feeling of responsibility of the success of ISUK and it becomes a learning process to be sensitive to problems faced, looking for solutions, and optimizing self-potentials. Optimization in psychological aspect, realization of individual potentials and building confidence to act further and in a macroscopic scale [20]. Putting self-potentials not only about independence in personal scope, but also be able to project it on the society.

Furthermore, the success of a program is also cannot be separated from collective awareness of an interdisciplinary collaborative work. Tyaga's strategic step by embracing health workers, health cadres, and the society to make a program together which leads to social institutionalization, becomes a key on the success of development. Keeping in mind that institutions is the origin of convention that is.... Because of the ability to unify various interests.... Can be seen as a network of rules and norms that govern social relationships [21].

\subsection{Visual Media, Transformation of Knowledge}

The indicator of society's welfare can be seen from the satiation of: educational, health, and economical factor. A crucial sector in Bugel village that must get more attention is education. It can be seen from how small the number of highly educated villagers, although higher education level does not always guarantee a broader knowledge. But knowledge has a strong correlation with education, where higher knowledge tends to be identical with extensive knowledge. Especially in the world we live in now, knowledge has a big role in the creation of important inventions to answer the problems faced by humans. It can be said that knowledge is a crucial aspect in every duration of humans' life, because knowledge is needed for the quality improvements in human humanize human. The portion of knowledge is used by humans in repairing, criticize, renew, erase what is inherited or their own creations, and creating new innovative things. Knowledge is the gate to the sciences in explaining the universe, knowing ourselves, aware of our existence and have unique characteristics compared to other people.

Based on the role of knowledge owned by humans, Tyaga initiates in creating learning media by printmaking posters. It is intended to give information with the educational contents to the society, and the information about healthcare services regarding society's welfare. Poster is an applied arts artwork with the function of promotion media for commercial and idea 
propagandas [22]. Posters' role besides being a media for information, it is also used as a motivation media by Tyaga as a stimulus for inspiring motivation, propulsive force to move Bugel villagers in solving the problems faced and doing beneficial things for their life.
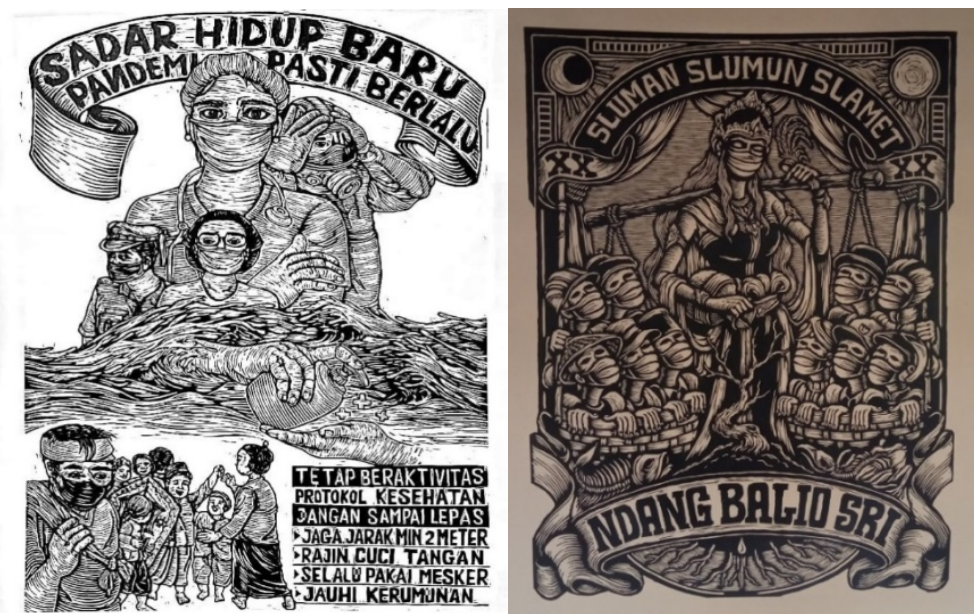

Picture 2. Right: Printmaking poster by Studio Raja Singa titled "Conscious of Health", Hardboard cut on paper, 90 x $60 \mathrm{~cm}, 2020$, edition 1 of 2; Left: Printmaking poster by Rochmat Basuki entitled "Ndang Balio Sri”, Hardboard cut on paper, 54 x 39 cm, 2020, edition 1 of 17 (Source: Studio Raja Singa, 2020).

The making of these posters is done as a recreational media for the villagers and also intended to increase the villagers' enthusiasm in supporting ISUK. These posters are displayed in public spaces in Bugel village and are also displayed in the village hall as the location where ISUK is held. They are also displayed online on Puskesmas Sekaran's social media and website. This is a form of cultural currents adaptation for Bugel villagers, which is inseparable from information and communication technology development.

The contents of the posters displayed include equality in cultural dynamics, introduction to health, hygiene, and environment, also independence spirit in development. These visual posters are intended for information, motivation, and knowledge transformation media for the villagers, keeping in mind that visual is a universal language which is easy to understand by the general public. Furthermore, through posters which consist of images and texts, it is capable to contain a lot of narration that includes ideas, information in a solid form and is easy to understand by public in general.

\section{Conclusion}

The problems in the society cannot be solved with only one perspective in certain discipline, but inter-territorial approach is needed, which is a combination of various discipline, profession, economic and technological. It is due to in assessing the society, it cannot be separated with current cultural changes that contextually relate to each other from various cultural elements. Whether it is regarding: art, economy, health, science, technology, belief, and social norms. The Reconciliation pattern done by Tyaga Art Management which accumulates various interdisciplinary could be a very strategic step in answering the villager's need in Bugel 
village, Sekaran sub-district, Lamongan district, East Java, Indonesia, or it can also be an offer in solving our problems together in this modern era, which meets the complexities that seems endless.

Tyaga as an art institution has a vision, that is building theory-action dialectic awareness in inclusivity to understand the reality in art and culture. Emphasizing the art activities cannot be separated from public empowerment. According to Muhamad Iqbal, art does not have meaning without the connection of life, human, and society. The purpose of art: .... To social education, .... For social improvement .... The true function of art is to reinvigorate passion, human, and society [20]. This view emphasizes art acts of Tyaga, in the current art activity which is empowering the health of the society and the environment. Concretely, the movement involving human resources from the society in the public empowerment act through health with the inter-territorial approach has the relevance in solving the problems in the society.

This research shows the involvement of the society in solving health and environment problems in Bugel village is good enough, and for the optimization of the success of the program it needs active argumentative role, knowledge expansion, decision making as a form of independence in solving problems faced by society.

Furthermore, besides the importance of development in health and education, it is also very possible for development in economy. It is can be done by recycling raw materials to be processed into valuable items with economical value. Keeping in mind the program ISUK is still in the development stage, which collects trash and distribute it to the garbage collectors without recycling process into usable items with a selling value. This processing step will indirectly improve the economy in Bugel village.

\section{References}

[1] Peraturan Menteri Kesehatan Republik Indonesia, Nomor 8 tahun 2019 Tentang Pemberdayaan Masyarakat Bidang Kesehatan. Jakarta.

[2] UNESCO, "Transdisciplinarity: Stimulating Synergies, Integrating Knowledge," UNESCO, 1998. [Online]. Available: http://unesdoc.unesco.org/images/0011/001146/114694eo.pdf.

[3] S. Najiyati, A. Asmana, and I. N. N. Suryadiputra, "Community empowerment on Peatlands," Canada's Progr. Wildl. Habitat, Bogor, 2005.

[4] B. S. Arifin, "Psikologi sosial." Pustaka Setia, 2015.

[5] Sumartono, Metode Penelitian Kualitatif Seni dan Desain. Jakarta: Pusat Studi reka Rancang Visual dan Lingkungan, 2017.

[6] E. Harburg, J. C. Erfurt, C. Chape, L. S. Hauenstein, W. J. Schull, and M. A. Schork, "Socioecological stressor areas and black-white blood pressure: Detroit," J. Chronic Dis., vol. 26, no. 9, pp. 595-611, 1973.

[7] D. R. Williams and C. Collins, "US socioeconomic and racial differences in health: patterns and explanations," Annu. Rev. Sociol., pp. 349-386, 1995.

[8] D. O. Sears, L. A. Peplau, and S. E. Taylor, "Psikologi sosial (edisi ke dua belas)," Jakarta Kencana Prenada Media Gr., 2009.

[9] R. Sugiarto, Psikologi raos: saintifikasi kawruh jiwa Ki Ageng Suryomentaram. Pustaka Ifada, 2015.

[10] A. Azra, Pendidikan Islam: tradisi dan modernisasi menuju milenium baru. Logos Wacana Ilmu, 1999.

[11] C. A. Van Peursen, "Susunan Ilmu Pengetahuan: Sebuah Pengantar Filsafat Ilmu.” PT. Gramedia, 1985.

[12] E. B. Hurlock, "Perkembangan Anak; Jilid 1," 1994.

[13] B. Sugiharto, Kebudayaan dan Kondisi Post-Tradisi: Kajian Filosofis atas Permasalahan Budaya Abad ke-21. PT Kanisius, 2019. 
[14] S. Pujileksono and M. Wuryantari, "Implementasi Teori, Teknik dan Prinsip Pekerjaan Sosial," Malang Intrans Publ., 2017.

[15] N. E. Adler, M. Marmot, B. S. McEwen, and J. Stewart, Socioeconomic Status and Health in Industrial Nation: Social, Psychologycal, and Biological Pathways. New York: Annals of the New York Academy of Sciences, 1999.

[16] S. Pujileksono, Sosiologi Pekerjaan Sosial. Malang: Intrans Publishing, 2019.

[17] F. T. Nasdian, Pengembangan masyarakat. Yayasan Pustaka Obor Indonesia, 2014.

[18] Soetomo, Pemberdayaan Masyarakat, Mungkinkah Muncul Antitesisnya? Yogyakarta: Pustaka Pelajar, 2011.

[19] S. Elhafiz, M. Nauly, R. Fauzi, and M. A. Hakim, "Psikologi sosial: Pengantar dalam teori dan penelitian," Salemba Humanika, 2018.

[20] A. Sachari, Estetika: makna, simbol dan daya. Penerbit ITB, 2002.

[21] H. Van Manaaner, How to Study Art Word. Amsterdam: Amsterdam University Press, 2009.

[22] M. Susanto, Diksi Rupa: Kumpulan Istilah dan Gerakan Seni Rupa. DictiArt Lab, 2011. 